\title{
CROSS-CULTURAL IMPLICATIONS OF THE PATTERNS OF GERMAN UTTERANCES IN TOUR GUIDING IN INDONESIA
}

\author{
Mery Dahlia Hutabarat \\ FPBS Universitas Pendidikan Indonesia \\ email: mery59@yahoo.de
}

\begin{abstract}
The purpose of this study is to describe the patterns of German utterances in tour guiding related to cross-cultural aspects. This was a qualitative descriptive study in which the data were collected through interviews and questionnaires. The findings show that the cross-cultural implications are manifested by tour guides' utterances to prepare a visit a tourist attraction. The utterances contain suggestion, information, and prohibition on doing things inappropriate for Indonesian culture such as how to shake hands and dress properly in a temple. Most utterances use the infinitive construction without a subject. They are communicative and understandable to German tourists. The utterances, however, do not seem to be polite enough based on German grammatical rules. Therefore, the patterns of utterances are designed for prospective German language speaking tour guides to learn.
\end{abstract}

Keywords:cross-cultural, Landeskunde, speaking, patterns of utterances, tour guiding

\section{IMPLIKASI SILANG BUDAYA POLA UJARAN BAHASA JERMAN DALAM PEMANDUAN WISATA DI INDONESIA}

\begin{abstract}
Abstrak
Penelitian ini bertujuan mendeskripsikan pola-pola ujaran bahasa Jerman dalam pemanduan wisata yang berkaitan dengan silang budaya. Metode penelitian adalah metode kualitatif deskriptif dengan menggunakan wawancara dan angket sebagai instrumen. Hasil penelitian menunjukkan bahwa implikasi silang budaya tampak pada ujaran pemandu wisata saat persiapan berkunjung ke objek wisata. Ujaran berisi anjuran, informasi, larangan melakukan hal-hal yang tidak sesuai dengan budaya Indonesia, misalnyacara bersalaman dan berpakaian yang sopan di candi/pura. Ujaran lebih banyak berbentuk konstruksi infinitif dan tanpa subjek. Ujaran yang dituturkan komunikatif dan dapat dipahami wisatawan Jerman. Akan tetapi, ujaran-ujaran tersebut dirasakan kurang santun apabila ditinjau dari kaidah tatabahasa Jerman. Oleh karena itu, Redemittel atau pola-pola ujaran disusun untuk dipelajari para calon pemandu wisata berbahasa Jerman.
\end{abstract}

Kata kunci: silang budaya, landeskunde, keterampilan berbicara, pola-pola ujaran, pemanduan wisata

\section{INTRODUCTION}

Cross-cultural communication in foreign countries tour guiding cannot be avoided. There are several complaints about tour guides skills, such as they can only speak speeches related to the visited attraction in monologue. They are expected to be able to understand the cultural background that becomes the rationale of the tourists they guide so that 
two way communications can happen. Tour guides speak chronologically about attraction or ceremony without speaking about the practical usage of a ceremony or the practical usage of a plant.

Another tour guide's task is to give briefing to the guest. The briefing is held at the hotel lobby and contains several things, such as: suggestion to behave in general to local citizen and in the sight visited, suggestion to shop and suggestion to use public transportation. Complaints including the German 'Landeskunde' knowledge gap owned by the tour guides are often heard.

The problem researched is limited to the cross-cultural aspect that implies the 'Redemittel' speech patterns in German speaking tour guides and the speech patterns spoken by the German tourists when visiting Indonesia.

This research aims to 1) describe the cross-cultural implication based on the perspective of the tour guides who can speak the German language, and 2) formulate Redemittel 'speech patterns' in cross-cultural communication during German speaking tour guiding in Indonesia.

This research is beneficial for the procurement of German language teaching material in courses related to tourism given since $2013 / 2014$ university curriculum is enforced. There are six courses in the new curriculum that are related to tourism, i.e.1) Einführung zum Tourismus 'Introduction to Tourism', 2) Nationaltourismus 'National Tourism', 3) Deutsch für Reiseführung 'German Language for Tourism', 4) Internationaltourismus 'International Tourism', 5) Deutsch für Hotelwesen 'German Language in Hospitality sector', and 6) Reiseführung 'Tour Guiding'.

Students who choose to take German language courses in tourism mentioned above will gain extensive knowledge and tourism specifics and a variety of tourism attractions not only in Indonesia but also in German speaking countries. After understanding the tourism attractions, students are given ample opportunity to practice their speaking skills in German in order to enable them to introduce the attractions to the German speaking tourists. Relating to speaking skills, Lado(1971: 278) gave a following definition:

"Wir definieren die mündliche Sprachproduktion oder Sprechfertigkeit als die Fähigkeit, in grundlegend normalen Kommunikationssituationen die Sygnalsysteme der Aussprache, der Betonung, der Intonation, der grammatischen Strukturen und des Vokabulars einer Fremdsprache zu benutzen, und zwar in einer für Sprecher dieser Sprache normalen Darbietungsgeschwindigkeit".

('Oral language production or speaking skills is defined as a skill to use the pronunciation, tone, intonation, grammar and vocabulary symbol system of a foreign language in a communication situation that is basically normal, and in a normal speaking tempo to the foreign language speaker').

The definition according Huneke et al. (2009: 109) was as follows:

„Sprechen ist die Haupttätigkeit, wenn man die Aufmerksamkeit andere auf sich lenken möchte, wenn man in der Interaktion mit anderen etwas erreichen möchte, wenn man Situation oder Verhalten von Gesprächspartnern den einigen Intentionen gemäß beeinflussen möchte, sei es unter vier Augen oder vor einer Gruppe, sei es privat oder öffentlich, sei es mit einen Vorgesetzten oder Lehrer oder mit Gleichgestellen".

('Speaking is a main activity if someone wants to divert others' attention to himself, if someone in his interaction with someone else want to achieve something, if someone based on his conversation purpose wants to 
influence a situation or the behavior of the speaking partner, either in a four eyes conversation or in group, either personally or generally, either with a supervisor or teacher or a fellow being').

The quote above shows the speaking purpose and who could be the speaking partner. The one meant as the speaker is a native Indonesian tour guide who can speak German. The speaking partner in guiding is a German native speaker from Germany, Austria or even German speaking Switzerland. To be able to speak as expected, learner should pay attention and read a lot as well as increase their vocabulary in certain themes and deepen their grammar. Thus, it was hoped that the graduates of the German Language Education Department who want to be a tour guide can speak German normally (not too slow or too fast).

In order to be able to achieve the speaking skills as expected above, learners study not only grammar and vocabulary, but also they are expected to internalize speech patterns called in German as Redemittel.

Redemittel is a composition that consists of nominal (die) Rede and (das) Mittel. Bußmann (1983: 426) gives three definitions for the Rede concept. One of them is: Vorgang und Ergebnis mündlicher oder schriftlicher Sprachproduktion. Meaning 'die Rede is a process and a production result of the oral and written language'.

Homberger (2000: 432) explained the nominal of Rede as Aktuelle gesprochene oder geschriebene Sprache ('Actual oral and written language'). The meaning of the nominal das Mittel according to Heuken (1987: 327) was 'means or tool'. Thus the definition of Redemittel is concluded as follows: Redemittel is the means or tool used to produce and the production result of oral and written language. Redemittel in German language learning book is always showed in the form of speech patterns that usually contains blank that must be filled according to the situation or context of the conversation.

Speech spoken on every conversation is not only in the form of one or two words. However, speaker must use a variety of speech patterns based on the spoken theme. In German language communication, there are general themes Redemittel that are standard, for example to open a conversation, to state an opinion, to agree with an opinion, to reject an opinion, etc. There are some that already are complete sentences, with subject, verb and object. The following are example of speech patterns in the German language learning book for level B1 and B2 based on the CEFR (Common European Framework of Reference) for Language in Europe. Some references in Perlmann-Balme and Schwalb $(2008,16)$ were as follows:

Example of Redemittel to open a conversation 'das Gespräch eröffnen'

(1) $($ Also, $)$ es geht hier um Folgendes: .... ' (So), this is related to .........'

(2) Im Grunde geht es um die Frage ..... 'Basically this is related to the question ..

Example to state an opinion 'Meinung äußern'

(3) Ich bin der Meinung, dass ..... 'I would argue that ...

(4) Ich denke, dass .... 'I think that .....'

The speech patterns above shows that there are blanks that must be filled with a sentence element according to the situation faced by the speaker.

In http://users.skynet.be/lit/redemittel. htm accessed on October 10, 2014, there are examples of Redemittel, such as

(5) Einen Augenblick! 'One moment!'

(6) Moment [bitte]! 'One moment!'

(7) Wie bitte? 'What?'

(8) Noch einmal bitte! 'Sorry, please repeat'.

(9) Sagen Sie es bitte noch einmal! 'Sorry, please say it once more!' 
(10) Sprechen Sie bitte langsam! 'Sorry, please speak slowly!

(11) Könnten Sie bitte noch langsamer/lauter sprechen? 'Can you please speak slower/ louder?'

(12) Ich habe Sie/das nicht verstanden! 'I don't understand it/ you'.

In German speaking exercise, Redemittel above are usually memorized by learner so that they can communicate well orally.

In addition to mastering Redemittel, learner shave studied cross-cultural aspects (Indonesia-Germany) which are integrated in all four language skills acquisition since they are in first semester. However, cross-cultural learning inrelation to tourism should be explicitly emerged in Redemittel. Therefore, the meaning of a term 'implication' is discussed here first. Lewandowski (1990: 428) said

Implikation (lat, Implicatio: Verflechtung, Verknüpfung). Folgebeziehung, Verknüpfung von Aussagen, die umgangssprachlich mit Sätzen vom Typ wenn... dann... bzw. Wenn ....., so .... ausgedrückt wird. Man sagt auch, $A$ impliziert $B$, und man verwendet die Wenn-dann-Verbindung, wenn man an inhatliche (temporale, konditionale, kausale u.a. Zusammenhänge denkt.

Meaning, Implication (originated from Latin implicatio: interdependence, linking). Consequence relationship, linking statements that are expressed colloquially insentence types: wenn (if)... dann (then)...or wenn (if).....so (so)..... It is also said, A implies B, and one uses wenn (if)...dann (then)-relation, if one thinks of content relationship (temporal, conditional, causal).

Similar opinion was also stated by Kunkel-Razum et al. (2003: 823). The term Implikation originated from the Latin word, implicatio $=$ Verflechtung. 1. Bildungsspr. Das Implizieren = Bedeutung: Einbeziehung einer Sache in eine andere. 2. Philos. Sprachw. Auf der Folgerung : wenn.... dann... = beruhende logische Beziehung.

Meaning, 'implication originated from the Latin word implicatio = interdependence. 1. Education language: implicating: means: relating one thing to another. 2. Philosophy language: on the impact of wenn 'if' dann ... 'then' = basic logical relations'.

The above discussion on implication associated with Redemittel 'speech pattern' can be concluded that the crosscultural concept implicates or affects the arrangement of the speech patterns used in the oral or written communication between language speakers.

Before discussing the cross-cultural concept, a concept related to „culture" and Landeskunde will be discussed first.

Mulyana et al. (2000; 25) said: Culture is a whole life pattern. Culture is complex, abstract and broad. There are lots of cultural aspects that also determine the communicative behavior.These sociocultural elements are spread and consist of many human social activities.

In German language, there is a (die) Kultur 'culture' concept. However, in German language learning, (die) Kultur is discussed in a 'Landeskunde' concept.

Kunkel-Razum et al.(2003: 987) said the definition of Landeskunde as follows:

Landeskunde, die (ohne Plural): Teilgebiet der Geographie, das sich mit der Erforschung und Darstellung der geographischen Gegebenheiten und Eigenarten von Ländern befasst.

Meaning: 'Landeskunde with the article die does not have a plural form. It is part of a geographical domain that researches and presents knowledge about geographical condition and uniqueness of every country'. Thus, Landeskunde knowledge is a knowledge that consists of everything existing in a country and its society. There is no word being equivalent to Landeskunde in Indonesian language. Therefore, 
the term Landeskunde is used in this research as it is without translation.

Kunkel-Razum et al. (2003: 841) gives definition to cross-cultural or interkulturell as follows: interkulturell (Adj.) die Beziehungen zwischen verschiedenen Kulturen betreffend. Meaning, interkulturell 'cross-cultural' is an adjective related to different intercultural relations.

If someone learns a foreign language, it is almost certain that person is involved in interkulturell learning. When a foreign language teacher asks learners to compare the situation in the target language text with the situation in the foreign language learner's self or environment, it automatically guides the learner to communicate in cross-cultural.

Samovar et al. (2010: 13) said: crosscultural communication involves interaction between people with quite different cultural perception and symbol system in a communication. Next, Samovar et al. (2010: 287) quoted the opinion of Pegel which said learning other language and culture helps you to think about the world with different dimension.

From the quotes above, it was known that if the communication practitioners are from two different cultures, they can not avoid cross-cultural communication. Likewise is the communication between a tour guide and tourists. It can start during greeting, opening a conversation, general behavior that must be followed by the tourists and the tour guide. Cross-cultural communication, either verbal or nonverbal cannot be avoided if communication practitioners are respectful to the speaking partner. Therefore, German tourists usually equip themselves with knowledge about the country and the society's culture in the country they will be visiting. Usually they read about books filled with information about a country. For example, in David (2010: 313) it was said Verhaltensknigge 'behavioral rule' for
German who will be visiting Indonesia. Those rules, for example, said as follow: Betont lockere und freizügige Freizeitkleidung ist für den Strand und das innerhäusliche Privatleben geeignet, aber nicht unbedingt für das Erscheinen in der Öffentlichkeit. Meaning, 'casual clothes which are loose and free only fit for beach and private life at home, but not to be worn in public places'.

Mit den Fingern aufMenschen zu weisen, ist sehr unhöflich. Lässt es sich aber doch mal nicht vermeiden oder will man in eine bestimmte Richtung zeigen, nimmt man nicht den Zeigefinger, sondern den rechten Daumen, wobei die Handinnenfläche nach oben zeigt und die Finger außer dem Daumen nach innen gebeugt sind. (David, 2010: 318)

Meaning: 'Pointing someone with an index finger is a very impolite gesture. If cannot be avoided, or if we want to point to a certain direction, it is better not to use the index finger but rather use the right thumb pointed to the object and palm faces up with other fingers fisted into the palm'.

Both examples above are a small part of cross- cultural knowledge that should be known by German speaking tourists when visiting Indonesia. The German speaking tour guides certainly know about it. However, a question shows up, can the tour guides compose German language speech that are proper and correct to convey this rule to German speaking tourists who do not prepare themselves or to tourists who have read but forget about the information?

\section{METHOD}

This research is a qualitative research and uses a descriptive method.

Data obtained in the form of speech are categorized into theme. Analysis of meaning is done by translating to the 
Indonesian language. Then, obtained Redemittel from the whole analyzed data are formulated.

Most of this research is done in Bandung, such as literature review, instrument composing, record-keeping or data transcription of interview result to written data, categorizing or data classification based on type of Redemittel, composing progress report and final research report as well as research result seminar. All those research activities were done in Bandung except for the interview in Bali and the research result seminar.

The research population is all tour guides that can speak German in all of Indonesia. The research sample is the reachable respondent. Interview with respondents who are German speaking tour guides and native German speaker respondents who are visiting Indonesia or working in Indonesia and have participated in German speaking tour guiding, most was done in Bali and Bandung. The interview was done directly with German native speaker tour guides and tourists in travel sights such as Bali, Jakarta, Bandung and surroundings. The interview was also done in two languages which are German and Indonesian.

Research data were obtained through questionnaire and interview. The questionnaire was written in two languages, which are Indonesian for German speaking Indonesian tour guides, and German for native German speaker tourists.

\section{RESULTS AND DISCUSSION Research Results}

Cross-cultural implication obtained from interview or questionnaire are described based on the themes, such as 1) general 'Verhalten' behavior, 2) clothes, 3) public facility consist of a) choosing place to exchange money, b) local transportation if traveling outside of the activity of the travel agent they used.
Tour guides accompanying tourist in travel usually faced with questions around the theme 4) plants, 5) religion and politics. The interview result transcription from replaying the interview records with five German speaking tour guide respondent can be said as follows:

\section{General 'Verhalten' Behavior Theme and theRedemittel for it \\ 'Begrüßung' Greeting: Usually} German tourist greets by holding tight their partner's hand and shake it as a sign that they are very pleased to meet the person. However it is not usual in Indonesian society because it is considered unpleasant. Therefore, the tour guides remind the German tourists of it. There is a female tour guide from Bandung that even teaches or asks the tourist to greet their partner as customarily in West Java.

(1) Wenn Sie jemanden begrüßen wollen, bitte greifen Sie ihm die Hand nicht fest zu. 'If you greet someone, please don't hold their hand firmly'.

(2) Oft führt man nach dem Handschlag die rechte Hand in Richtung des Herzens.' After shaking hand, the right hand used to shake hand is pulled to the chest'.

(3) Wenn Sie Frauen (vor allem die ein Kopftuch tragen) begrüßen wollen, warten Sie lieber ab und sehen, wie man sie begrüßen sollte. Manche sehen das als verboten an, Menschen des anderen Geschlechts zu berühren. 'If you want to greet a woman (especially woman with hijab), it is better that you wait and see how others greet them. Some think it is prohibited to touch someone with opposite gender (sex)'.

(4) Wenn es der Fall ist, legen Sie bitte die beiden Handinnenflächen aneinander vor der Brust, oder führen Sie die beiden Hände an die Brust. 'In such situation, please press both your palm and place it in front of your chest or pull both your palms to your chest'. 
Körpersprache'Body Language': German tourists are advised to use their right thumb, if they want to point someone or to a certain direction. The palm position must face up and the other four fingers must be bent in to the palm. The Redemittel for that says:

(5) Wenn Sie eine bestimmte Richtung oder eine Person zeigen wollen, nehmen Sie nicht den Zeigefinger, sondern den rechten Daumen. Die Handinnenfläche zeigt nach oben und die Finger außer dem Daumen beugen Sie nach innen. If you want to point to a certain direction or someone, don't use your index finger, but rather your right thumb. Palm faces up and the other four fingers fisted inside the palm'.

Using Right Hand: Tourists must use their right hand when giving or receiving something from their speaking partner. Indonesian consider left hand as unclean since it was used to clean when in the toilet. The Redemittel for that states;

(6) Wenn Sie jemandem etwas geben oder von jemandem etwas nehmen wollen, bitte benutzen Sie dabei immer die rechte Hand. Sonst wird das als unhöflich empfunden und das gilt als unrein, weil die linke Hand aufder Toilette benutzt wird. 'If you want to give something to someone or receives something from someone, you must use your right hand. If not, then it is considered impolite and left hand is considered unclean because it was used in the toilet'.

\section{The Prohibition to Touch Children's Head especially Boys}

If tourists meet with boys, the German tourists are prohibited to touch the head of the boy that come up to them because it was considered as taboo. If they want to touch the boys, it was suggested that they stroke or touch the boys' shoulder. The Redemittel for that says:
(7) Wenn Sie Kinder unterwegs treffen, und die Kinder kommen zu Ihnen und reden Sie freundlich und höflich an, bitte streicheln Sie ihre Köpfe nicht. Das gilt hier als tabu. Es ist genug, wenn Sie die Kinder an die Schulter berühren. 'If you meet children on your traveling and they come to you and greet you friendly and politely, please don't touch their heads. It was considered as taboo here. Instead you touch enough their shoulder'.

Prohibition to Kiss the Hand of Women who are not their Mahram (men or women who are still close relatives because of heredity or marital relationship so as not to be married).

As it was mentioned in Redemittel point (3) and (4) above, tourists are not allowed to touch women who are not their mahram even though the guests want to give thanks in their own way. The Redemittel for that states:

(8) Wenn Sie sich bei einer fremden Frau bedanken oder eine fremde Frau bewundern wollen, bitte küssen Sie ihr die Hand nicht. Das gilt hier nach moslemischen Regeln als verboten.'

If you want to thank to an Indonesian woman who you don't know well or if you want to convey your admiration to that woman, you are not allowed to kiss her hand. According to Islam, it is prohibited'.

If you want to thank a strange woman or admire her, please do not kiss her hand. That applies hereby Moslem rules as prohibited.

Kleidung 'Clothing Theme'

Daily Clothing

Principally tourists are suggested to wear clothes that cover their shoulder and pants that cover their knee. Wearing long pants is not a must because the air is pretty hot for the German tourists. However, they are not allowed to wear swimsuit or bikini when they wander in public 
places. Swimsuit or bikini is only allowed to be worn in swimming pool during sunbathing or at beach during swimming. The Redemittel for that states:

(9) Bitte bekleiden Sie sich "anständig". Ein Mann sollte ein kurzärmliges T-Shirt und eine lange Hose oder eine Hose, die die Knie bedeckt, tragen. Frauen sollten eine Hose oder auch einen Rock tragen. Wichtig ist, dass die Hose oder der Rock die Knie bedeckt. 'Dress politely. Men must wear T-Shirt and long pants or short pants that cover the knees. Women must wear pants or skirt that cover the knees'.

(10) Ziehen Sie sich locker und freizügig nur in Ihrem Hotelzimmer an. Bitte erscheinen Sie sich so in der Öffentlichkeit. 'If you wear loose and casual clothes, do it in your hotel room. Don't show up in front of the public like that'.

There are times when the tourists are taken to visit certain places where the temperature are $20^{\circ} \mathrm{C}$. Therefore, the tourists are asked to bring 'Pulli' or 'Pullover' sweater. Respondent explains that the guest will travel to mountain with an open jeep. In the mountain area the temperature is around $20^{\circ} \mathrm{C}$. Therefore, it is suggested that they bring sweater. The Redemittel for that sounds as follows:

(11) Cabrio, Offendach-Jeep. Dafür brauchen Sie einen Pulli oder Pullover. Der Sarong ist schon im Auto. Dann brauchen Sie keinen Sarong auszuleihen. Der Pulli, wissen Sie. Der Temperatur ist kalt. $20^{\circ}$ C. Das ist doch kalt. 'Cabrio, open jeep. Therefore you need Pullover sweater. Sarongs are available in the car. So you don't need to rent sarongs, Pulli 'sweater'. Cold temperature. $20^{\circ} \mathrm{C}$. That is cold'.

'Tempelkleidung' Clothing in the Temple

Tourists are required to wear sarong in the temple. Sarong can be rented in the counters before entering the temple. The rent price is told (between Rp. 5000 to Rp. 10 000). Usually the German tourists would be pleased to follow the suggestion. The male tourists also want to use Udeng 'head's ornament' that are usually worn by the Balinese men during prayer. The use of sarong and udeng is considered by the German tourist as an interesting experience. Following is the Redemittel for that:

(12) (Am Freitag haben Sie das Programm der geheimnisvollen Osten). Da besuchen Sie auch einen Tempel. Deshalb müssen Sie einen Sarong ausleihen, den Sie nur aufdem Tempel tragen. Bei dem Ausflug können Sie ein T-Shirt anziehen. 'Your event for Friday is the East area that is full of secrets. You will also visit a temple. Therefore, you must rent a sarong and it will only be worn inside the temple. During the tour, your will only need to wear T-Shirt'.

Additional information on sarong rental is also given during the talking hour given by the representative in the hotel lobby. Following is the Redemittel for that:

(13) Dort gibt es Sarong mit besonderem Muster. Sie können einen Sarong im Schalter vor dem Tempel ausleihen. Das kostet nicht viel, so zwischen fünf Tausend bis sieben Tausend Rupiah. 'There will be sarong with certain pattern. You can rent it in the rental counter in front of the temple. The rental fee is not expensive between five thousand to seven thousand rupiah'.

The Redemittel to use sarong can also be composed as follows:

(14) In diesem Programm werden Sie einen Tempel besuchen. Bitte ziehen Sie dort einen Sarong an. Im Prinzip müssen Sie die Schulter und das Knie bedecken. Sie brauchen keine lange Hose zu tragen. Sie können Ihren eigenen Sarong mitnehmen, oder Sie können am Schalter vor dem 
Tempel einen Sarong ausleihen. Das kostet nicht viel. Also ungefähr fünf bis 10 Tausend Rupiah. 'In this program you will visit the temple. You wear sarong there. Principally you must cover your shoulder and knee. You can bring your own sarong or rent it in the counter in front of the temple. The price is not expensive around five to 10 thousand rupiah'.

Other Rule for Women who will enter the Temple

The female tourists are given an information that they are not allowed to enter the temple if they are on their period. There is no controlling in the temple's gate but they are asked to respect the temple and not to violate this rule. The Redemittel for that is:

(15) Es gibt auch andere Verhaltensregeln, einen Tempel zu besuchen. Das gilt für Frauen. Wenn Sie die Menstruation gerade haben, dürfen Sie nicht in den Tempel hinein kommen. Das gilt als unrein oder unsauber. Es wird zwar nicht kontrolliert, aber bitte respektieren Sie das. 'There is also another rule for visiting a temple. The rule applies to women. If you are on your period, you are not allowed to enter the temple. It is considered unholy or unclean. It will not be inspected but please respect them'.

\section{Choosing Money Changer}

The tourists are prohibited to exchange their money in a kiosk that has other merchant beside it such as Coca Cola seller. Such money changer is not good. Usually an honest Money Changer have its own place and have a convincing name plate, for example on the name plate it will said Auto Risk Money Changer. The Redemittel to choose money changer is formulated as follow:

(16) Wenn Sie Geld wechseln wollen, gehen Sie zu einem Money Changer, das nicht mit anderen Geschäften zusammen steht. Da sind Tafeln zu sehen, auf denen die Wechselpreise zu lesen sind. Aber Sie sollten sich das ganze Gebäude anschauen, ob das Geschäft Money changer mit Kuchen-Verkäufer und Getränke-Verkäufer zusammen steht. Das ist kein gutes Money changer. Normalerweise hat ein gutes Geschäft money changer mit einem Namenschild, zum Beispiel Auto Risk Money Changer, das ist das beste. 'If you want to exchange your money, go to a money changer that is not adjacent with other stores. In there, there will be an information board for foreign exchange price. However you must pay attention to the whole building where the money changer is, is it side by side with pastries seller and drink seller. Such money changer is not good. Usually a good money changer has a name plate, e.g. Auto Risk Money Changer. That is the best.

\section{Public Transportation}

Tourists are suggested to use taxi with a certain brand. The travel cost is also mentioned based on the traveled distance.

(17) Wenn Sie zu irgendeinem Supermarkt gehen, der ein bisschen weit weg von Ihrem Hotel ist, nehmen Sie das Taxi NN. Das zeigt auch am Argometer, wie viel Sie bezahlen müssen. 'If you want to go to a Supermarket that is quite far from your hotel, use NN taxi. The argometer will show the price you need to pay'.

\section{Plants and Food Theme}

Talks about plants usually happen when tour guiding is on their way to an attraction or sight. Lots of German tourists are interested in the rice plant. They want to know the type of rice and their usage, the history of rice, how to cultivate the soil, how long the rice is planted until harvest time. 
Other plant that often asked is coffee. German loves to drink coffee, tour guides then must be able to explain about coffee. The time needed to explain about coffee sometimes can spend an hour, it depends on the interest of the tourists. Therefore, the literature about coffee must also be known by tour guides. The types of coffee are such as Arabica and Robusta and also Luwak coffee.

If the communication about coffee has been accomplished, usually it will be followed by invitation to drink coffee together. The effect of the invitation is very positive. The problem shown up previously starts to melt usually with one coffee invitation and good personal touch with German language. German tourist would also like to know the names of Indonesian food. They saw in the menu, there are always nasi goreng (fried rice), bakmie goreng (fried noodles). In the end, they will know that they are Indonesian food.

\section{Political and Religious Theme}

German speaking tour guides should prepare themselves with hot news on politics in Indonesia. It will be better, if the tour guides can compare it with the political situation in Germany.

There are tour guides that relates political theme with Indonesian history. Recent news must also be followed because German guests mostly prepare themselves and will ask if the information they had read or listened is true.

According to respondent, German people are very open minded. They even understand very well the difference that is even to them very preposterous. The way of thinking and understanding of local culture are very good. Their longing to come to Bali to see its beauty is not only as tourists, but also the most important thing is the cultural background. They are very interested in how the Balinese culture as Hindus are, how Hindus culture with daily life are. As Balinese truly believe in God, in ancestors.

\section{Discussion}

In tour guiding especially in a long trip from North Sumatera to Bali, German speaking tourists usually like tour guides who are able to explain the attraction calmly, in a slow pace, and not in a hurry, because there are tourists who want to take notes on what the tour guide explains. In addition to that, hospitality and an always smiling face (even if in reality the tour guides are tired due to the long trip) make tour in Indonesia fun and soothing. Especially if there is a kinship feeling between the tour guide and the tourists. Happiness and laughter of the tour guide will make a tiring trip be a fun one.

On the contrary, tour guides who speak German in a very fast pace when explaining the attraction (perhaps because they have recited it) will make the tourists tired. Especially in a German language that is very influenced by dialect from one of the regions in Indonesia. It really bothers the tourists. Some will immediately do the siebzehn trick which is pretending to sleep and snore because they don't understand what is being explained.

Cross-cultural matters that are quite bothering is the greeting of " $i b u$ " (mother) to all Indonesian women. The greeting is a bit confusing to the German speaking tourists. All adult women can be greeted with the word "ibu". There are some children who address their biological mother with the word "ibu". There also some husband who call their wife "ibu". Thus, it seemed that there is no difference in intimate feeling to a beloved family. It is different with greeting in German language, starting from the formal level Sie 'Anda' (You) who applies to all gender, which is a greeting of first person to second person, both singular and plural (You all). Greeting for informal level has the pronouns $d u$ ' $k a m u$ ' (you) for second 
person in singular and for all gender and ihr 'kalian' (you all) for second person in plural. To greet biological mother, the noun Mutter/Mutti 'ibunda' (mother), for biological father there is Vater/Vatti 'ayahanda' (father).

The attitude of German people (tourist) who should be traced by the Indonesian tour guides is Tugend 'wisdom', for example always keeping the promise especially time promise to finish something. The timeliness of German people are highly appreciated and adhered by tour guides. Therefore, respondents who work as tour guides always try hard so that everything that has already planned can run according to the schedule agreed together or stated in the program. Therefore, it can be said that German speaking Indonesian tour guides belong to a group of Indonesian community that keep the agreed time.

Things in a similar tone with obedience can be mentioned as follows. German speaking tour guides are very obedient to behavior prohibitions and regulations that they have heard from the tour guides or Gästebetreuer 'representative' from the hotel who give directions on how to behave generally in Indonesia, especially in the region site that they are visiting. They do not ask why they have to act in a certain way. Where as plenty of German people always ask why they have to do things that are not prevalent with their culture. Many of them try to adapt to the situation in Indonesia even though it is undeniable that there are German speaking tourists who experience culture shock on the bus that bring them from the Sukarno-Hatta airport through Jakarta to the tour destination. Spontaneously the tourist wanted to immediately return to their country. The culture shock that was experienced happened due to seeing the traffic chaos in Indonesia. However, with the patience of the tour guide in persuading and promising a relaxing and beautiful situation in their tour destination, the tourist will finally feel happy in their trip.

In using the Indonesian language, many of the German speaking tourists who come to Indonesia repeatedly (repeat guest) try to learn autodidactly and use the Indonesian language when they meet other Indonesian people (other than tour guide). Although the speech that they are expressing consists of brief greeting "Good Evening", Good Afternoon”, , ,How are you?" and thanking in the Indonesian language. According to them, speaking in Indonesian in a simpler level is not so hard to learn because the way of writing and pronunciating of the symbols in Indonesian language are the same. It is easier and done usually to communicate in a simple way with the Indonesian people who they meet in a restaurant, a hotel or during shopping when they are not accompanied by a tour guide. The food that they bought, are usually Indonesian food. During their staying in Indonesia, they think that they should also taste Indonesian food. It shows that crosscultural aspects happened by the German speaking tourist.

Some of the research results are contrary to the expectation of the researcher, such as there are a few prohibitions that must be obeyed by the German tourists. For example they are not allowed to shake hand by holding tight their speaking partner's hand and shake it. They were even asked to copy how Indonesian people shake hands. According to the researcher, this is a bit excessive because based on the cultural background the researcher has, shaking hand by holding hand tightly is a common thing.

The prohibition to touch a boy's head is also a new finding for the researcher. This is unimaginable from the beginning. The compliance of the German tourists not to do things that are prohibited is 
also a positive value in the cross-cultural life. The compliance of the German people to follow the existing rules is not something new. This can be seen from their compliance to follow the German language grammar that is very complex and compliance to the existence of gender for every nominal named article and the change based on the four cases.

Approximately $80 \%$ of 25 German language Redemittel 'speech pattern' used by tour guides are only infinitive construction. The description of the speeches used by the tour guides are sentences or phrases that they used to speak. Therefore the German tourists can understand the speeches even though there are errors so that the speeches are considered by them as good and proper. If the tour guide's speech transcriptions are analyzed based on the German language rules, many grammatical errors happened. Despite of the fact the tourists can understand the speech. However, what appears in this writing is the fact that the Redemittel has been improved, either the choosing of the vocabulary, sentence structure or grammar.

\section{CONCLUSION AND SUGGESTIONS Conclusion}

Cross-cultural implication is showed on the behavior of tour guides and on the speech patterns used to give information to the German tourists. The information generally contains of how to behave in Indonesia, either general behavior or how to dress in public places and in the temple. German respondents who come to Indonesia for the first time recommend that tour guiding in the German language should not be spoken in a fast tempo because a dialect that is slipped in the intonation of the tour guide will increasingly obscure the meaning of the information conveyed. They wish that the tour guide gives time to the German tourist to digest the information that they have received. Moreover, there are respondents who want to take notes during tour so that they can repeat and speak about it again in the future to their relativesor acquaintance who have never visited Indonesia. Respondents who are repeat guests also learn the Indonesian language autodidactly and try to use the speeches what they have learned with the Indonesian people as their speaking partners in a restaurant or other public places.

The Indonesian respondents working as tour guides have done their job well in the tour field by using German speeches that are understandable by native German speaking tourists. Misunderstanding that happened due to the difficulty to convey information in German can be overcome easily by simplifying the speeches using infinitive construction, meaning that the respondents do not have to compose speeches in German sentences according to the correct grammar. Communication between German tourists and German speaking tour guides is quite satisfying. Among the guests guided, there are some who become repeat guests 'subscriber' because they are pleased to spend their holiday in Indonesia.

Although most of the Germanspeaking tour guides use the infinitive construction in form to explain something to the tourists. It does not influence the communication among themselves. However, it would be better, if tour guides explain it in the right form of commonly used German expressions.

\section{SUGGESTIONS}

Redemittel or 'speech patterns' that were described in this research are still limited to giving information related to cross-cultural implication. There are still a lot of themes that have not been discussed in this research because of the limited time and fund. Those themes are in the form of brief knowledge on variety of important 
plants in Indonesia, religious ritual ceremonies held by Indonesian family and other themes previously mentioned. Therefore, it is suggested to carry out further research on teaching materials related to Indonesian Landeskunde. Besides, research on the teaching material related to attraction or sights held the interest of German tourist, research on method, strategy or teaching materials in tourism should also be done, so that future German speaking tour guides can give information using the German speech patterns that are correct and proper according to the German grammatical rules.

\section{REFERENCES}

Bußmann, H. 1983. Lexikon der Sprachwissenschaft. Stuttgart: Alfred Körner Verlag.

David, B. 2010. Kulturschock Indonesien. Osnabrücker: Reise Know + How. Verlag Peter Rump.

Heuken, A. 1987. Kamus Jerman Indonesia. Jakarta: Penerbit Gramedia.

Homberger, D. 2000. Sachwörterbuch zur Sprachwissenschaft. Stuttgart: Philipp Reclam jun.
Huneke, H. Von Schmidt, W. 2009. Deutsch als Fremdsprache. Eine Einführung. Berlin: Erich Schmidt Verlag.

Lado, R. 1971. Moderner Sprachunterricht. Eine Einführung auf wissenschaftliche Grundlage. Übersetzte Version von Freudenstein, Rheinhold. München; Hueber Verlag.

Kunkel-Razum, K. Schulze-Stubenrecht, W. Wermke, M. (Ed.). 2003. DUDEN. Deutsches Universalswörterbuch. Mannheim: Dudenverlag.

Lewandowski, T. 1990. Linguistisches Wörterbuch Band 2. Wiesbaden: Quelle \& Meyer Verlag

Mulyana, D. Rakhmat, J. 2000. Komunikasi Antarbudaya. Panduan Berkomunikasi dengan Orang-orang Berbeda Budaya. Bandung: Penerbit PT. Remaja Rosdakarya.

Perlmann-Balme, M. Schwalb, S. 2008. Em neu 2008. Hauptkurs. Ausgabe. München; Hueber Verlag.

Samovar, L. A. Porter, R. E. McDaniel. E. R. 2010. Komunikasi Lintas Budaya. Edisi 7. Translator: Indri Margaretha Sidabalok. Jakarta; Salemba Humanika. http://users.skynet.be/lit/redemittel.htm 